\title{
PENGEMBANGAN MODEL PERMAINAN DALAM PEMBELAJARAN RENANG UNTUK MAHASISWA
}

\author{
Whalsen Duli Agus Lauh', Ilham Surya Fallo², Utami Dewi ${ }^{3}$ \\ IKIP PGRI Pontianak ${ }^{1,2,3}$ \\ whalsenduli@gmail.com ${ }^{1}$
}

\begin{abstract}
Abstrak
Penelitian ini bertujuan untuk mengetahui (1) bentuk model permainan dalam pembelajaran renang untuk mahasiswa. (2) Hasil pelaksanaan tahap uji coba pada kelompok kecil dan kelompok besar model permainan dalam pembelajaran renang untuk mahasiswa. Metode penelitian yang digunakan yaitu penelitian pengembangan. Hasil penelitian yang diperoleh yaitu (1) Tersusunnya 15 bentuk model permainan dalam pembelajaran renang dengan unsur meliputi: nama permainan, tujuan permainan, peralatan yang butuhkan, jumlah peserta dan aturan permainan. (2) Pada uji penggunaan model permainan oleh mahasiswa dalam uji coba kelompok kecil, terlihat bahwa model permainan yang dikembangkan memperoleh rata-rata skor 3,11 dengan kategori sangat baik dan pada uji penggunaan model permainan pada uji coba kelompok besar diperoleh rata-rata skor 3,28 dengan kategori sangat baik. Dari hasil tersebut dapat artikan bahwa model permainan untuk pembelajaran renang yang dikembangkan peneliti mendapatkan respon positif dari mahasiswa dan dapat diterapkan dalam pembelajaran renang untuk mahasiswa.
\end{abstract}

Kata Kunci: Pengembangan, Model Permainan, Pembelajaran Renang

\section{DEVELOPMENT MODELS GAME IN LEARNING SWIMMING FOR STUDENTS}

\begin{abstract}
This study aims to determine (1) the form of game models in swimming learning for students. (2) The results of the implementation of the pilot phase in small groups and large groups of game models in swimming learning for students. The research method used is development research. The results obtained are (1) The compilation of 15 forms of game models in swimming learning with elements including: the name of the game, the purpose of the game, the equipment needed, the number of participants and the rules of the game, (2) In testing the use of game models by students in small group trials, it is seen that the game models developed obtain an average score of 3.11 with very good categories and in the test of the use of game models in large group trials an average score is obtained 3.28 with a very good category. From these results it can be interpreted that the game model for swimming learning developed by researchers received a positive response from students and can be applied in swimming learning for college students.
\end{abstract}

Keywords: Development, Game Model, Swimming Learning

Correspondence author: Whalsen Duli Agus Lauh, Ilham Surya Fallo, Utami Dewi, IKIP PGRI Pontianak, Indonesia. E-Mail: whalsenduli@gmail.com

Jurnal HalamanOlahraga Nusantara licensed under a Creative Commons Attribution-ShareAlike 4.0 International License. 


\section{PENDAHULUAN}

Olahraga terus berkembang dengan pesat seiring dengan perkembangan modernisasi dan teknologi yang makin canggih dengan adanya berbagai karakteristik dalam bentuk kebutuhan, kesibukan, dan gaya hidup. Menurut Rosdiani (2012) bahwa pertumbuhan macam-macam olahraga, tidak terlepas dari pengaruh keadaan sosial budaya, kondisi ekonomi, geografis dan juga politik. Ilmu pengetahuan dan teknologi yang terus maju dengan pesat mengharuskan setiap orang belajar terus menerus, selalu ditemukan sesuatu yang baru yang berarti orang yang pasif atau diam pastinya akan ketinggalan segala perkembangan yang ada saat ini.

Pendidikan di Indonesia telah menempatkan olahraga sebagai salah satu media pembentukan karakter anak bangsa yang sesuai dengan budaya bangsa Indonesia serta mencerminkan nilai-nilai pancasila. Upaya meningkatkan kualitas sumber daya manusia, ilmu olahraga diarahkan pada peningkatan kualitas jasmani, mental dan rohani, serta ditunjukan untuk membentuk watak dan kepribadiaan, disiplin dan sportivitas yang tinggi, serta peningkatan prestasi, meningkatkan moral bangsa (Lesmana, 2019). Pada hakikatnya pembelajaran khususnya di perguruan tinggi yaitu proses interaksi edukatif antara mahasiswa dengan lingkungannya, seperti interaksi dengan Dosen, materi, metode, sarana dan prasarana, media pembelajaran, lingkungan sosial dsb, hal tersebut sejalan dengan Ningrum (2014) yang mengemukakan bahwa pembelajaran adalah serangkaian kegiatan yang melibatkan informasi dan lingkungan yang disusun secara terencana untuk memudahkan siswa dalam belajar. Faktor-faktor tersebut selalu berhubungan dan saling mempengaruhi dalam proses pembelajaran. Salah satu cabang olahraga yang turut ambil bagian dalam dunia pendidikan di indonesia adalah cabang olahraga renang yang diimplementasikan dalam proses pembelajaran di semua level pendidikan, termasuk di perguruan tinggi.

Pembelajaran renang melibatkan aktivitas jasmani yang dilakukan dengan sungguh-sungguh untuk mencapai tujuan pembelajarannya. Melalui penggunaan model yang tepat yaitu salah satunya modifikasi permainan, diharapkan dengan sendirinya tujuan pembelajaran renang akan mudah dicapai karena mahasiswa 
akan melakukan aktivitas jasmani dengan sukarela, sungguh-sungguh dan dalam suasana yang menyenangkan. Imansyah (2018) mengatakan renang sebagai olahraga yang salah satu dari sekian olahraga yang digemari dari berbagai kalangan di masyarakat, karena renang dapat dilaksanakan oleh anak-anak dan orang dewasa laki-laki ataupun perempuan. Olahraga renang mempunyai tujuan yang bermacam-macam diantaranya untuk olahraga pendidikan, olahraga rekreasi, rehabilitasi, dan olahraga prestasi.

Permainan merupakan suatu aktivitas yang sangat digemari pada semua jenjang umur terutama pada usia anak hingga remaja. Konsep pembelajaran yang dikemas dalam aktivitas permainan akan secara tidak langsung membuat seseorang tertarik dan berminat untuk ikut terlibat secara aktif dalam kegiatan permainan tanpa menyadari bahwa sebenarnya dia telah terlibat dalam proses pembelajaran. Menurut Abdillah (2019) mengatakan bahwa kegiatan dalam pelaksanaan pendidikan jasmani yang bisa mengajak anak bergerak secara aktif yaitu permainan yang bisa memberi kesenangan dan kompetisi sederhana. Modifikasi permainan yang diterapkan dalam pembelajaran akan mempermudah dosen dan mahasiswa karena semua peralatan yang diperlukan dapat disesuaikan dengan kondisi serta sumber daya yang ada. Selain itu, modifikasi permainan juga akan menuntut kreatifitas yang tinggi baik bagi Dosen maupun mahasiswa.

Pengamatan yang peneliti lakukan pada mahasiswa IKIP PGRI Pontianak Program Studi Penjaskesrek khususnya pada Mata Kuliah Pembelajaran Renang, mayoritas mahasiswa sudah bisa berenang namun belum menguasai keempat gaya secara baik. Untuk efektifitas pembelajaran maka perlu adanya suatu model pembelajaran yang tepat yang dalam hal ini yaitu modifikasi permainan untuk menunjang keberhasilan dalam proses perkuliahan.

\section{METODE}

Penelitian ini menggunakan metode penelitian pengembangan, karena sesuai dengan masalah yang ditemukan dalam studi pendahuluan, sehingga untuk memecahkan kesenjangan antara harapan dan kenyataan yang terjadi, maka jenis penelitian pengembangan merupakan jenis penelitian yang tepat untuk 
menyelesaikan masalah tersebut. Menurut Harjanto (2011) model merupakan sebuah hal yang bisa menggambarkan pola berpikir seseorang. Sebuah model biasanya menggambarkan keseluruhan konsep yang saling berkaitan. Model bisa dianggap sebagai suatu upaya mengkonkretkan sebuah teori sekaligus juga merupakan sebuah analogi dan representasi dari variabelvariabel yang terdapat dalam teori tersebut.

Penelitian pengembangan model permainan dalam pembelajaran renang untuk mahasiswa ini dimulai dengan studi pendahuluan, pembuatan produk, penilaian ahli, uji coba kelompok kecil, revisi, uji coba kelompok besar dan revisi. Dengan keterbatasan waktu dan biaya maka penelitian ini hanya sampai pada tahap uji coba kelompok besar.

Mulyatiningsih (2012) menjelaskan 4 langkah pengembangan yakni model 4D yang terdiri dari :

\section{Define}

Pada tahap ini dilakukan untuk menetapkan dan mendefinisikan syarat-syarat pengembangan. Dalam penelitian ini tahap define adalah merumuskan desain permainan dalam pembelajaran renang yang meliputi materi pokok, tujuan, strategi, dan produk latihan. Selanjutnya menentukan tema dan tempat penelitian.

\section{Design}

Tahap ini peneliti sudah membuat produk awal atau rancangan produk. Pada konteks pengembangan model permainan, tahap ini dilakukan untuk membuat materi sesuai hasil analisis materi yang akan disajikan.

3. Development

Pada tahap ini ada tiga kegiatan yaitu pengembangan produk, validasi atau penilaian rancangan produk dan ujicoba rancangan produk ke subjek.

\section{Disseminate}

Pada tahap ini terdapat tiga kegiatan yaitu: validation testing, packaging, diffusion and adoption. 
Subjek penelitian pengembangan ini ada dua yaitu, subjek validasi produk dan subyek ujicoba produk.

1. Subyek validasi produk

a. Ahli Materi yang berjumlah 1 orang, yaitu adalah dosen atau akademisi olahraga renang yang berperan untuk menentukan dan menilai materi yang ada dalam produk pengembangan sesuai tingkat kebenaran dan kedalaman materi.

b. Pelatih Berlisensi 1 orang, yaitu pelatih atau pakar yang ahli dalam hal olahraga renang. Pelatih ahli berperan menilai produk pengembangan yang dibuat dari segi kesesuaian substansi materi dan bentuk permainan yang disajikan.

2. Subjek uji coba produk

a. Dosen renang yang berjumlah 1 orang, yaitu Dosen sekaligus pelatih atau pengajar di IKIP PGRI Pontianak.

b. Mahasiswa IKIP PGRI Pontianak, dimana 12 orang mahasiswa untuk uji coba kelompok kecil dan 24 orang untuk uji coba kelompok besar.

Tempat penelitian ini dilaksanakan di kolam renang ampera untuk penilaian produk oleh ahli materi, dosen dan juga mahasiswa. Penelitian ini dilaksanakan pada bulan Juni sampai dengan Agustus 2019, sedangkan pada tahap penyusunan laporan dilaksanakan pada bulan September 2019.

Teknik pengumpulan data digunakan untuk mendapatkan data meliputi data kondisi awal, data hasil uji ahli renang dan data hasil uji coba kelompok. Teknik pengumpulan data yang digunakan dalam penelitian ini dijabarkan yaitu teknik observasi dan teknik angket/quisioner. Instrument yang digunakan yaitu angket/kuisioner dan dokumentasi.

Instrumen penelitian yang digunakan ada dua bentuk kuesioner, yaitu:

a. Kuesioner untuk ahli dan dosen renang

Penilaian ahli renang terhadap produk pengembangan model permainan.

Penilaian berdasarkan aspek kesesuaian, aspek kemanfaatan, aspek keamanan dan aspek keterlaksanaan.

b. Kuesioner untuk mahasiswa 
Penilaian mahasiswa terhadap produk. Penilaian berdasarkan aspek kemudahan untuk dipahami, aspek kemudahan untuk dilakukan, aspek kemenarikan dan aspek kemanfaatan.

Instrumen angket disusun dengan beberapa indikator penilaian materi untuk ahli maupun mahasiswa. Kisi-kisi instrumen angket/kuisioner dapat dilihat pada table berikut ini:

Tabel 1. Kisi-kisi Instrumen Untuk Ahli

\begin{tabular}{|c|c|c|c|}
\hline Variabel & Indikator & Sub Indikator & Butir Soal \\
\hline \multirow{13}{*}{$\begin{array}{l}\text { Permainan dalam } \\
\text { Pembelajaran } \\
\text { Renang }\end{array}$} & \multirow{3}{*}{$\begin{array}{l}\text { Kesesuaian } \\
\text { produk } \\
\text { dengan } \\
\text { Tujuan } \\
\text { pembelajaran }\end{array}$} & 1. Kognitif & $1,2,3$ \\
\hline & & 2. Afektif & $4,5,6$ \\
\hline & & 3. Psikomotor & $7,8,9$ \\
\hline & \multirow{3}{*}{$\begin{array}{l}\text { Kesesuaian } \\
\text { produk } \\
\text { dengan } \\
\text { kebutuhan } \\
\text { peserta didik }\end{array}$} & $\begin{array}{l}\text { 1. Memenuhi kebutuhan } \\
\text { gerak }\end{array}$ & $10,11,12$ \\
\hline & & $\begin{array}{l}\text { 2. Memenuhi kebutuhan } \\
\text { berinteraksi }\end{array}$ & $13,14,15$ \\
\hline & & $\begin{array}{l}\text { 3. Memberikan pengetahuan } \\
\text { baru }\end{array}$ & 16,17 \\
\hline & \multirow{3}{*}{$\begin{array}{l}\text { Kesesuaian } \\
\text { produk } \\
\text { dengan materi } \\
\text { renang }\end{array}$} & $\begin{array}{l}\text { 1. Memenuhi kebutuhan } \\
\text { materi pembelajaran } \\
\text { renang }\end{array}$ & 18,19 \\
\hline & & $\begin{array}{l}\text { 2. Memperhatikan aspek } \\
\text { psikologis peserta didik }\end{array}$ & 20,21 \\
\hline & & $\begin{array}{l}\text { 3. Memperhatikan aspek } \\
\text { keamanan }\end{array}$ & 22,23 \\
\hline & \multirow{4}{*}{$\begin{array}{l}\text { Produk Materi } \\
\text { permainan }\end{array}$} & 1. Mudah difahami & 24,25 \\
\hline & & 2. Mudah dilakukan & 26,27 \\
\hline & & 3. Menyenangkan & 28,29 \\
\hline & & 4. Kreatifitas & 30 \\
\hline
\end{tabular}


Tabel 2. Kisi-kisi Instrumen Angket Untuk Mahasiswa

\begin{tabular}{|c|c|c|c|}
\hline Variabel & Indikator & Sub Indikator & Butir Soal \\
\hline \multirow{13}{*}{$\begin{array}{l}\text { Permainan dalam } \\
\text { Pembelajaran } \\
\text { Renang }\end{array}$} & \multirow{3}{*}{$\begin{array}{l}\text { Kesesuaian } \\
\text { produk } \\
\text { dengan } \\
\text { Tujuan } \\
\text { pembelajaran }\end{array}$} & 1. Kognitif & $1,2,3$ \\
\hline & & 2. Afektif & $4,5,6$ \\
\hline & & 3. Psikomotor & $7,8,9$ \\
\hline & \multirow{3}{*}{$\begin{array}{l}\text { Kesesuaian } \\
\text { produk } \\
\text { dengan } \\
\text { kebutuhan } \\
\text { peserta didik }\end{array}$} & $\begin{array}{l}\text { 1. Memenuhi kebutuhan } \\
\text { gerak }\end{array}$ & $10,11,12$ \\
\hline & & $\begin{array}{l}\text { 2. Memenuhi kebutuhan } \\
\text { berinteraksi }\end{array}$ & $13,14,15$ \\
\hline & & $\begin{array}{l}\text { 3. Memberikan pengetahuan } \\
\text { baru }\end{array}$ & 16,17 \\
\hline & \multirow{3}{*}{$\begin{array}{l}\text { Kesesuaian } \\
\text { produk } \\
\text { dengan materi } \\
\text { renang }\end{array}$} & $\begin{array}{l}\text { 1. Memenuhi kebutuhan } \\
\text { materi pembelajaran } \\
\text { renang }\end{array}$ & 18,19 \\
\hline & & $\begin{array}{l}\text { 2. Memperhatikan aspek } \\
\text { psikologis peserta didik }\end{array}$ & 20,21 \\
\hline & & $\begin{array}{l}\text { 3. Memperhatikan aspek } \\
\text { keamanan }\end{array}$ & 22,23 \\
\hline & \multirow{4}{*}{$\begin{array}{l}\text { Produk Materi } \\
\text { permainan }\end{array}$} & 1. Mudah difahami & 24,25 \\
\hline & & 2. Mudah dilakukan & 26,27 \\
\hline & & 3. Menyenangkan & 28,29 \\
\hline & & 4. Kreatifitas & 30 \\
\hline
\end{tabular}

\section{HASIL DAN PEMBAHASAN}

\section{Hasil Uji Penggunaan Model Permainan oleh Dosen Pengajar}

Setelah dilakukan validasi model permainan oleh ahli materi dan pelatih berlisensi, produk direvisi berdasarkan komentar dan saran dari ahli materi dan pelatih berlisensi. Produk yang sudah direvisi tersebut digunakan dalam pembelajaran renang melalui uji coba kelompok kecil atau terbatas dan uji coba kelompok besar. Uji penggunaan model permainan dilakukan oleh dosen renang prodi Penjaskesrek. Uji coba penggunaan model permainan dalam pembelajaran renang tersebut merupakan proses pengembangan produk untuk menghasilkan model permainan yang layak digunakan dalam pembelajaran renang untuk mahasiswa di perguruan tinggi serta memberikan alternatif model pembelajaran dalam pelaksanaan proses perkuliahan renang.

Hasil uji penggunaan model permainan oleh dosen renang dalam uji coba kelompok kecil adalah sebagai berikut: 
Tabel 3 Hasil Uji Penggunaan Model Permainan oleh Dosen dalam Uji Coba Kelompok Kecil

\begin{tabular}{lccc}
\hline \multirow{2}{*}{ Aspek Penilaian } & \multicolumn{3}{c}{ Penilaian Dosen } \\
\cline { 2 - 4 } & $\begin{array}{c}\text { Jumlah } \\
\text { Skor }\end{array}$ & $\begin{array}{c}\text { Rata-rata } \\
\text { Skor }\end{array}$ & Kategori \\
\hline Kemudahan difahami & 13 & 2,60 & Baik \\
\hline Kemudahan dilakukan & 14 & 2,80 & Baik \\
\hline Kemenarikan & 21 & 3,00 & Sangat Baik \\
\hline Kemanfaatan & 21 & 3,50 & Sangat Baik \\
\hline
\end{tabular}

Sumber: Data penelitian yang diolah

Angket respon mengenai model permainan dalam penelitian ini juga disediakan kolom saran dan masukan yang diisi oleh dosen renang sehingga dapat diperoleh gambaran tindakan berikutnya untuk model permainan tersebut. Adapun rangkuman hasil saran dan masukan dari dosen renang terhadap model permainan dalam tahap uji coba kelompok kecil ini dapat dilihat pada Tabel 4 di bawah ini.

Tabel 4. Saran dan Masukan dari Dosen Renang

\begin{tabular}{clrlr}
\hline No & \multicolumn{3}{c}{ Saran dan Masukan } & \multicolumn{2}{c}{ Perbaikan } \\
\hline 1 & $\begin{array}{l}\text { Alat yang digunakan untuk } \\
\text { permainan } \\
\text { menggunakan alat yang tidak } \\
\text { mengotori air kolam }\end{array}$ & $\begin{array}{l}\text { Menggunakan alat yang } \\
\text { terbuat dari plastik dan bersih }\end{array}$ \\
\hline 2 & Gunakan alat yang mudah didapat & $\begin{array}{l}\text { Menggunakan barang bekas } \\
\text { yang mudah dimodifikasi }\end{array}$ \\
\hline
\end{tabular}

Berdasarkan Tabel 4 di atas dapat diketahui bahwa model permainan dalam penelitian ini perlu perbaikan khususnya pada aspek peralatan yang digunakan untuk permainan.

Setelah dilakukan uji penggunaan model permainan dalam pembelajaran renang oleh dosen dalam uji coba kelompok kecil dan revisi, selanjutnya dilakukan uji penggunaan model permainan oleh dosen dalam uji coba kelompok besar. Hasil uji penggunaan model permainan dalam uji coba kelompok besar dapat dilihat pada Tabel 5 berikut: 
Tabel 5 Hasil Uji Penggunaan Model Permainan oleh Dosen dalam Uji Coba Kelompok Besar

\begin{tabular}{lccc}
\hline \multirow{2}{*}{ Aspek Penilaian } & \multicolumn{3}{c}{ Penilaian Dosen } \\
\cline { 2 - 4 } & $\begin{array}{c}\text { Jumlah } \\
\text { Skor }\end{array}$ & $\begin{array}{c}\text { Rata-rata } \\
\text { Skor }\end{array}$ & Kategori \\
\hline Kemudahan difahami & 17 & 3,40 & Sangat Baik \\
\hline Kemudahan dilakukan & 16 & 3,20 & Sangan Baik \\
\hline Kemenarikan & 25 & 3,57 & Sangat Baik \\
\hline Kemanfaatan & 22 & 3,67 & Sangat Baik \\
\hline Sumber: Data penelitian yang diolah & &
\end{tabular}

Rangkuman hasil saran dan masukan dari dosen renang terhadap model permainan dalam tahap uji coba kelompok besar dapat dilihat pada Tabel 6 berikut:

Tabel 6. Saran dan Masukan dari Dosen Renang

\begin{tabular}{clc}
\hline \multicolumn{1}{c}{ Saran dan Masukan } & \multicolumn{1}{c}{ Perbaikan } \\
\hline Aturan permainan sedikit rumit & $\begin{array}{l}\text { Aturan permainan dibuat simpel } \\
\text { dan mudah difahami }\end{array}$ \\
\hline
\end{tabular}

Berdasarkan Tabel 6 dapat diketahui bahwa model permainan dalam penelitian ini perlu perbaikan kecil khususnya pada aspek aturan permainan.

\section{Hasil Uji Penggunaan Model Permainan oleh Mahasiswa}

Uji penggunaan model permainan oleh mahasiswa dilakukan di IKIP PGRI Pontianak pada mahasiswa mata kuliah renang. Pelaksanaan uji penggunaan model permainan ini dilakukan sebanyak dua kali, yaitu dalam uji coba kelompok kecil dan uji coba kelompok besar.

Hasil uji penggunaan model permainan oleh mahasiswa dalam uji coba kelompok kecil adalah sebagai berikut: 
Tabel 7 Hasil Uji Penggunaan Model Permainan oleh Mahasiswa dalam Uji Coba Kelompok Kecil

\begin{tabular}{ccccc}
\hline No & Mahasiswa & $\begin{array}{c}\text { Jumlah } \\
\text { Skor }\end{array}$ & $\begin{array}{c}\text { Rata-rata } \\
\text { Skor }\end{array}$ & Kategori \\
\hline 1 & Mahasiswa 1 & 67 & 2,91 & Baik \\
\hline 2 & Mahasiswa 2 & 74 & 3,22 & Sangat Baik \\
\hline 3 & Mahasiswa 3 & 73 & 3,17 & Sangat Baik \\
\hline 4 & Mahasiswa 4 & 70 & 3,04 & Sangat Baik \\
\hline 5 & Mahasiswa 5 & 70 & 3,04 & Sangat Baik \\
\hline 6 & Mahasiswa 6 & 73 & 3,17 & Sangat Baik \\
\hline 7 & Mahasiswa 7 & 71 & 3,09 & Sangat Baik \\
\hline 8 & Mahasiswa 8 & 73 & 3,17 & Sangat Baik \\
\hline 9 & Mahasiswa 9 & 74 & 3,22 & Sangat Baik \\
\hline 10 & Mahasiswa 10 & 72 & 3,13 & Sangat Baik \\
\hline 11 & Mahasiswa 11 & 70 & 3,04 & Sangat Baik \\
\hline 12 & Mahasiswa 12 & 70 & 3,04 & Sangat Baik \\
\hline & Rata-rata & $\mathbf{7 1 , 4 2}$ & $\mathbf{3 , 1 1}$ & Sangat Baik \\
Jumlah Skor & & &
\end{tabular}

Sumber: Data penelitian yang diolah

Berdasarkan Tabel 7 diketahui bahwa rata-rata skor penilaian mahasiswa terhadap model permainan dalam uji coba kelompok kecil sebesar 3,11 dengan kategori Sangat Baik. Setelah dilakukan uji coba kelompok kecil, terdapat saransaran dan masukan dari mahasiswa mengenai model permainan. Berikut rangkuman hasil saran dan masukan dari mahasiswa terhadap model permainan dalam tahap uji coba kelompok kecil ini dapat dilihat pada Tabel 9 di bawah ini.

Tabel 8. Saran dan Masukan dari Mahasiswa

\begin{tabular}{clccl}
\hline No & \multicolumn{2}{c}{ Saran dan Masukan } & \multicolumn{1}{c}{ Perbaikan } \\
\hline 1 & $\begin{array}{l}\text { Durasi } \\
\text { singkat }\end{array}$ & permainan & terlalu & Durasi permainan ditambah \\
\hline 2 & $\begin{array}{l}\text { Kurang } \\
\text { aturan permainan }\end{array}$ & tentang & $\begin{array}{l}\text { Penjelasan awal tentang aturan } \\
\text { main sebelum memulai permainan }\end{array}$ \\
\hline
\end{tabular}

Berdasarkan Tabel 8 di atas dapat diketahui bahwa model permainan dalam penelitian ini perlu perbaikan khususnya pada aspek durasi waktu permainan dan aturan permainan.

Setelah dilakukan uji penggunaan model permainan oleh mahasiswa dalam uji coba kelompok kecil, selanjutnya dilakukan uji coba kelompok besar. Hasil 
uji penggunaan model permainan dalam uji coba kelompok besar dapat dilihat pada Tabel 9 sebagai berikut:

Tabel 9. Hasil Uji Penggunaan Model Permainan oleh Mahasiswa dalam Uji Coba Kelompok Besar

\begin{tabular}{ccccc}
\hline No & Mahasiswa & $\begin{array}{c}\text { Jumlah } \\
\text { Skor }\end{array}$ & $\begin{array}{c}\text { Rata-rata } \\
\text { Skor }\end{array}$ & Kategori \\
\hline 1 & Mahasiswa 1 & 72 & 3,13 & Sangat Baik \\
\hline 2 & Mahasiswa 2 & 75 & 3,26 & Sangat Baik \\
\hline 3 & Mahasiswa 3 & 74 & 3,22 & Sangat Baik \\
\hline 4 & Mahasiswa 4 & 74 & 3,22 & Sangat Baik \\
\hline 5 & Mahasiswa 5 & 73 & 3,17 & Sangat Baik \\
\hline 6 & Mahasiswa 6 & 76 & 3,30 & Sangat Baik \\
\hline 7 & Mahasiswa 7 & 74 & 3,22 & Sangat Baik \\
\hline 8 & Mahasiswa 8 & 77 & 3,35 & Sangat Baik \\
\hline 9 & Mahasiswa 9 & 77 & 3,35 & Sangat Baik \\
\hline 10 & Mahasiswa 10 & 78 & 3,39 & Sangat Baik \\
\hline 11 & Mahasiswa 11 & 74 & 3,22 & Sangat Baik \\
\hline 12 & Mahasiswa 12 & 77 & 3,35 & Sangat Baik \\
\hline 13 & Mahasiswa 13 & 78 & 3,39 & Sangat Baik \\
\hline 14 & Mahasiswa 14 & 78 & 3,39 & Sangat Baik \\
\hline 15 & Mahasiswa 15 & 77 & 3,35 & Sangat Baik \\
\hline 16 & Mahasiswa 16 & 75 & 3,26 & Sangat Baik \\
\hline 17 & Mahasiswa 17 & 79 & 3,43 & Sangat Baik \\
\hline 18 & Mahasiswa 18 & 77 & 3,35 & Sangat Baik \\
\hline 19 & Mahasiswa 19 & 76 & 3,30 & Sangat Baik \\
\hline 20 & Mahasiswa 20 & 75 & 3,26 & Sangat Baik \\
\hline 21 & Mahasiswa 21 & 75 & 3,26 & Sangat Baik \\
\hline 22 & Mahasiswa 22 & 75 & 3,26 & Sangat Baik \\
\hline 23 & Mahasiswa 23 & 73 & 3,17 & Sangat Baik \\
\hline 24 & Mahasiswa 24 & 71 & 3,09 & Sangat Baik \\
\hline & Rata-rata & $\mathbf{7 5 , 4 2}$ & $\mathbf{3 , 2 8}$ & Sangat Baik \\
\hline Jumlah Skor & & & \\
\hline & & & & \\
\hline
\end{tabular}

Berdasarkan hasil uji penggunaan model permainan oleh mahasiswa di atas, diketahui bahwa model permainan yang dikembangkan melewati proses revisi dan uji penggunaan sebanyak dua kali yakni uji kelompok kecil dan uji kelompok besar. Pada uji penggunaan model permainan oleh mahasiswa dalam uji coba kelompok kecil, terlihat bahwa model permainan yang dikembangkan memperoleh rata-rata skor 3,11 dengan kategori sangat baik dan pada uji penggunaan model permainan pada uji coba kelompok besar diperoleh rata-rata skor 3,28 dengan kategori sangat baik. Dari hasil tersebut dapat artikan bahwa 
model permainan untuk pembelajaran renang yang dikembangkan peneliti mendapatkan respon positif dari mahasiswa.

Rangkuman hasil saran dan masukan dari dosen renang terhadap model permainan dalam tahap uji coba kelompok besar dapat dilihat pada Tabel 10 berikut.

Tabel 10. Saran dan Masukan dari Dosen Renang

\begin{tabular}{|c|c|c|}
\hline No & Saran dan Masukan & Perbaikan \\
\hline 1 & $\begin{array}{l}\text { Alat yang digunakan untuk } \\
\text { permainan } \\
\text { menggunakan alat yang tidak } \\
\text { mengotori air kolam }\end{array}$ & $\begin{array}{l}\text { Menggunakan alat yang terbuat dari } \\
\text { plastik dan bersih }\end{array}$ \\
\hline 2 & Gunakan alat yang mudah didapat & $\begin{array}{l}\text { Menggunakan barang bekas yang } \\
\text { mudah dimodifikasi }\end{array}$ \\
\hline 3 & Aturan permainan sedikit rumit & $\begin{array}{l}\text { Aturan permainan dibuat simpel } \\
\text { dan mudah difahami }\end{array}$ \\
\hline
\end{tabular}

Berdasarkan Tabel 10 dapat diketahui bahwa model permainan dalam penelitian ini perlu perbaikan kecil khususnya pada aspek kemudahan difahami dan kemudahan dilakukan.

Berdasarkan hasil penelitian diatas, dapat disimpulkan bahwa model permainan untuk pembelajaran renang sudah memenuhi kelayakan untuk digunakan dan dikembangkan. Namun produk model permainan ini belum melewati uji efektifitas sehingga belum diketahui seberapa tinggi efektifitasnya dalam pembelajaran renang.

\section{Pembahasan}

Berenang ialah segala aktivitas yang dilakukan di dalam air dengan tujuan melatih peserta didik untuk meningkatkan kemampuan motorik di air. Aktivitas renang merupakan segala macam bentuk aktivitas air yang dapat dilakukan di sungai, danau, laut, pantai, maupun kolam renang. Karnadi (2007) yang menyatakan bahwa olahraga renang secara umum disebut juga olahraga air, yang mana di dalamnya mencakup permainan, perlombaan, bahkan hal-hal yang berhubungan dengan keselamatan terutama bagi orang-orang yang memiliki kegiatan sehari-harinya berhubungan dengan alam hal ini air, seperti dengan 
kolam renang, wisata bahari, kehidupan di pinggir sungai, berkaitan dengan itu setiap orang dituntut memiliki pengetahuan dan keterampilan tentang olahraga renang

Pendekatan pembelajaran renang mahasiswa dilakukan dengan mempertimbangkan sumber daya yang tersedia dan kemampuan dasar berenang yang kemudian dikemas dalam bentuk permainan dengan mengedepankan situasi yang menyenangkan dengan menggunakan strategi, metode, materi dan media yang menarik serta mudah dilakukan. Rusman (2012) menyatakan bahwa penentuan model pembelajaran yang akan digunakan dalam kegiatan pembelajaran harus mempertimbangkan: (a) tujuan yang hendak dicapai, (b) bahan atau materi pembelajaran, (c) peserta didik, dan (d) pertimbangan lainnya yang bersifat nonteknis. Melalui model permainan yang dikembangkan, mahasiswa diajak untuk bereksplorasi, menemukan dan memanfaatkan objekobjek yang mudah dicari, sehingga pembelajaran menjadi mudah dan menyenangkan sehingga pendekatan permainan akan sangat menunjang keberhasilan proses perkuliahan renang karena menyentuh ranah kognitif, afektif dan psikomotor mahasiswa. Sungkowo \& Rahardjo (2012) bahwa pada sistem pendidikan nasional rumusan dari tujuan pendidikan nasional, tujuan kurikuler dan juga tujuan instruksional, dapat melakukan klasifikasi dari hasil belajar Bloom secara garis besar dapat dibagi menjadi tiga ranah yakni ranah kognitif, ranah afektif, dan ranah psikomotor. Hal ini diperkuat oleh Kurniawan \& Suharjana (2018) dalam penelitiannya yang menyimpulkan bahwa "Model permainan polo air sebagai pembelajaran pendidikan jasmani bagi siswa sekolah dasar kelas atas efektif dilaksanakan dalam proses pembelajaran karena dapat mengembangkan nilai-nilai pada aspek kognitif, afektif, dan psikomotor”.

Hakikat permainan yaitu aktivitas jasmani yang dilakukan dengan sungguh- sungguh, sukarela, dan menyenangkan. Seperti yang dikemukakan oleh Juliantine (2010)Bermain pada intinya adalah aktivitas yang digunakan sebagai hiburan. Kita mengartikan bermain sebagai hiburan yang bersifat fisikal yang tidak kompetitif, meskipun bermain tidak harus selalu bersifat fisik. Bermain bukanlah berarti olahraga dan pendidikan jasmani, meskipun elemen dari bermain 
dapat ditemukan di dalam keduanya. Pembelajaran renang juga melibatkan aktivitas jasmani yang dilakukan dengan sungguh-sungguh untuk mencapai tujuan pembelajarannya. Melalui pendekatan bermain tujuan pembelajaran akan mudah dicapai karena peserta didik akan melakukan aktivitas jasmani dengan sukarela, gembira, dan menyenangkan.

Mahasiswa Penjaskesrek merupakan calon-calon guru Penjasorkes yang akan menjadi tenaga pendidik di Sekolah. Sangat penting untuk membekali mereka dengan kemampuan dan pengetahuan tentang model pembelajaran yang dapat diterapkan khususnya dalam renang. Melalui pengembangan model permainan ini diharapkan dapat menambah wawasan dan pengalaman bagi mahasiswa dalam menerapkan pembelajaran renang.

\section{Kesimpulan}

Berdasarkan proses penelitian yang telah dilakukan serta analisis data, maka kesimpulan yang dihasilkan dalam penelitian ini yaitu: Tersusunnya 15 bentuk model permainan dalam pembelajaran renang dengan unsur meliputi: nama permainan, tujuan permainan, peralatan yang butuhkan, jumlah peserta dan aturan permainan. Pada uji penggunaan model permainan oleh mahasiswa dalam uji coba kelompok kecil, terlihat bahwa model permainan yang dikembangkan memperoleh rata-rata skor 3,11 dengan kategori sangat baik dan pada uji penggunaan model permainan pada uji coba kelompok besar diperoleh rata-rata skor 3,28 dengan kategori sangat baik. Dari hasil tersebut dapat artikan bahwa model permainan untuk pembelajaran renang yang dikembangkan peneliti mendapatkan respon positif dari mahasiswa dan dapat diterapkan dalam pembelajaran renang untuk mahasiswa.

\section{DAFTAR PUSTAKA}

Abdillah, A. (2019). Pengembangan Model Pembelajaran Motorik Berbasis Permainan. Jurnal Pendidikan Olahraga, 8(2), 138-147.

Harjanto. (2011). Perencanaan Pengajaran.

Imansyah, F. (2018). Hubungan Antara Kekuatan Otot Tungkai Dan Kekuatan Otot Lengan Terhadap Hasil Kecepatan Renang 50 Meter Gaya Bebas 
Pada Atlet Putri Club Bangka Swimming. Halaman Olahraga Nusantara (Jurnal Ilmu Keolahragaan), 1(1).

Juliantine, T. (2010). Strategi Mengajar Melalui Model Bermain Dalam Mata Pelajaran Pendidikan Jasmani Di Sekolah Dasar. Motion: Journal Research Of Physical Education, 1(1), 1-9.

Karnadi, I. (2007). Renang. Jakarta: Universitas Terbuka.

Kurniawan, W. P., \& Suharjana, S. (2018). Pengembangan model permainan poloair sebagai pembelajaran pendidikan jasmani bagi siswa sekolah dasar kelas atas. Jurnal Pendidikan Jasmani Indonesia, 14(2), 50-61.

Lesmana, H. S. (2019). Profil delayed onset muscle soreness (doms) pada mahasiswa fik unp $\mathrm{se}^{\mathrm{TEL}} \mathrm{ah}$ latihan fisik. Halaman olahraga Nusantara (Jurnal Ilmu Keolahragaan), 2(1), 50-59.

Mulyatiningsih, E. (2012). Applied Research Methods in Education. Bandung: Alfabeta, 194-195.

Ningrum, J. S. (2014). Strategi Pembelajaran Teori \& Aplikasi. Jogjakarta: ArRuzz Media.

Rosdiani, D. (2012). Dinamika olahraga dan pengembangan nilai. Bandung: Alfabeta.

Rusman, D., \& Pd, M. (2012). Model-model pembelajaran. Raja Grafindo, Jakarta.

Sungkowo, S., \& Rahardjo, H. P. (2012). Pengembangan Pembelajaran Renang Melalui Pendekatan Bermain Motor Boat Estafet. ACTIVE: Journal of Physical Education, Sport, Health and Recreation, 1(5). 